\title{
Penologia jako podstawa polityki karnej. Wybrane teoretyczne kwestie prawne związane z pracą kuratora sądowego
}

\section{Wstęp}

W artykule krytycznie rozważam z różnych perspektyw wybrane teoretyczne aspekty funkcjonowania prawa w kontekście pracy kuratora sądowego. Nawiązuję pośrednio do różnych koncepcji prawa, w tym dość luźno do koncepcji Georga Jellinka normatywnej siły faktu, a więc siły kształtującej w szczególny sposób relacje między władzą i obywatelem. To właśnie w kontekście rzeczywistych realiów stosowania prawa kurator sądowy bezpośrednio realizuje zadania wymiaru sprawiedliwości wobec podsądnych i ich rodzin, stając się swoistym mediatorem-tłumaczem między prawdą sądową, faktami relewantnymi prawnie a rzeczywistym życiem doświadczanym przez osoby, których dotyczy postępowanie. W postępowaniu prowadzonym na podstawie ustawy kurator sądowy występuje przede wszystkim jako funkcjonariusz publiczny, który działa na zlecenie sądu na podstawie i w granicach prawa wobec osób, których kontakt i podstawy współpracy z kuratorem są wynikiem decyzji sądu, a nie wolnego wyboru. Kurator sądowy ma realizować zadania w zakresie wychowania i resocjalizacji, diagnozy, profilaktyki oraz kontroli tak, aby zarówno chronić dobra społeczne, jak i w odpowiednim zakresie dobra podsądnych, zależnie od rodzaju zastosowanego wobec nich środka. Kurator sądowy ma zawsze realizować zadania wyłącznie zgodnie z literą prawa i wyrokiem sądu. Rodzić to może napięcie między interesem podopiecznych, ich rozumieniem rzeczywistości i własnego dobra oraz sytuacji - czasami także interesem społecznym - a określeniem zadań kuratora przez prawo pozytywne i wyrok sądu. Może powstać konflikt między prawdą wynikającą z doświadczenia współpracy z podopiecznym i znajomością szerokich uwarunkowań psychospołecznych danej sytuacji, której postępowanie dotyczy, a formalnymi uwarunkowaniami wykonywanej pracy. Napięcie to można postrzegać w obecnym ustroju z perspektywy podstawowej wartości ustrojowej godności ludzkiej i - w języku teorii prawa - dotyczy problemu relacji między ogólną ideą prawa a normą prawa pozytywnego i spełnieniem tej normy w rzeczywistości społecznej. Ta teoretyczna perspektywa stanowi podstawę analizy 
aporii, jaką stwarza rozbieżność między literą prawa i sprawiedliwością a treścią spełnionej normy pozytywnej, czego jedynie ekstremalnym przypadkiem jest ustawowe bezprawie w rozumieniu znanej koncepcji Gustava Radbrucha. Warto zwrócić uwagę, że na poziomie oficjalnych deklaracji zasada praworządności - jako odpowiednio synonim państwa prawa - obowiązywała w Polsce także do 1989 r. w ustroju socjalistycznym, co wyrażał m.in. obowiązujący do dzisiaj kodeks postępowania administracyjnego' (art. 6-11 k.p.a.), a konstytucja PRL z 1952 r. ${ }^{2}$ przesycona była deklaracjami humanistycznymi na temat praw obywatelskich. Ponadto, przynajmniej od końca lat siedemdziesiątych XX w. PRL była związana ustaleniami Aktu Końcowego KBWE na temat praw człowieka, ratyfikowała także Międzynarodowy Pakt Praw Obywatelskich i Politycznych ONZ, a więc niewątpliwie deklarowała poszanowanie podstawowych praw podmiotowych człowieka i obywatela. Uważa się, że ówczesny typ reżimu politycznego i typ państwa nie stwarzał jednak gwarancji ustrojowych i politycznych praw obywateli, nie był więc to na pewno model władzy respektujący zasady demokratycznego państwa prawnego. Przyjmuje się, że rzeczywisty respekt dla praw człowieka i obywatela może w państwie wynikać wyłącznie z podporządkowania systemu politycznego regułom proceduralnym demokracji i rozwiązaniom ustrojowym, stwarzającym realne gwarancje realizacji deklaracji normatywnych odnośnie praw i wolności jednostek. Przede wszystkim - istotne jest w takim ustroju rzeczywiste upodmiotowienie obywateli, w tym upowszechnienie prawa dostępu do niezależnego i niezawisłego sądu.

W sensie formalnoprawnym i postulatywno-normatywnym Polska stała się demokratycznym państwem prawa na podstawie noweli konstytucji PRL z 29 grudnia 1989 r. ${ }^{3}$ Przyjęcie tej koncepcji ustrojowej było realizacją aspiracji i postulatów wolnościowych polskiej opozycji demokratycznej, w szczególności szerokiego kręgu środowisk prawniczych, a także jednym z warunków umożliwiających wejście Polski do grona europejskich państw demokratycznych członków Rady Europy - sygnatariuszy europejskiej Konwencji o ochronie praw człowieka i podstawowych wolności (EKPC). Szczególną rolę w promowaniu koncepcji demokratycznego państwa prawnego odegrał promotor mojej pracy doktorskiej - profesor Michał Pietrzak. Lata dziewięćdziesiąte XX w. to okres, w którym wielokrotnie zwracano uwagę na to, aby całe ustawodawstwo respektowało podstawowe standardy państwa prawnego, w tym aby podstawą całego ustroju było poszanowanie praw człowieka. Rozwijano więc doktrynę praw człowieka. Jej intensywny rozwój stymulowany był w szczególności przyjęciem przez Polskę kognicji Europejskiej Komisji (Trybunału) Praw Człowieka w Strasburgu, a zwieńczeniem dążenia do oparcia ustawodawstwa na respekcie dla praw człowieka stała się Konstytucja

\footnotetext{
1 Ustawa z dnia 14 czerwca 1960 r. - Kodeks postępowania administracyjnego (Dz. U. Nr 30, poz.168; dalej: k.p.a.).

2 Konstytucja Polskiej Rzeczypospolitej Ludowej uchwalona przez Sejm Ustawodawczy w dniu 22 lipca 1952 r. (Dz. U. Nr 33, poz. 232).

3 Ustawa z dnia 29 grudnia 1989 r. o zmianie Konstytucji Polskiej Rzeczypospolitej Ludowej (Dz. U. $\mathrm{Nr} 75$, poz. 444 ze zm.).
} 
z 1997 r. ${ }^{4}$ z bardzo szerokim katalogiem praw i wolności człowieka. Rozważając aksjologiczne podstawy ustroju państwowego, duże znaczenie przypisuje się art. 30 Konstytucji, który odnosi się do aksjologicznej podstawowej wartości, za jaką uznaje się przyrodzoną i niezbywalną godność (każdego) człowieka. To respekt dla godności (każdego) człowieka - rozumianej jako element sfery powinności, a nie bytu (Sollen, a nie Sein), rozpisany na szczegółowe zasady określające prawa podmiotowe osób oraz zobowiązania władzy publicznej - stanowi, obok odpowiednio organizowanych wolnych wyborów, podstawę legitymizmu nowego ustroju państwowego. Z dzisiejszej perspektywy Polski po transformacji ustrojowej nie wydaje się zasadne koncentrowanie uwagi na niewątpliwej wyższości obecnego reżimu politycznego i ustroju państwowego nad czasami PRL, lecz ważniejsza jest krytyczna analiza realizacji idei państwa prawa w obecnych warunkach ustrojowych. Tym bardziej, że wzrost znaczenia prawa w nowym ustroju określany jako jurydyzacja życia społecznego nie jest tylko wynikiem zmiany polityczno-ustrojowej. Jurydyzacja życia społecznego i zwiększanie praw podmiotowych jednostek, ale też wzrost złożoności i skomplikowania prawa muszą być postrzegane jako wyraz szerszych przemian cywilizacyjnych. Są to bowiem procesy, które występują w ostatnich kilku dekadach bardzo wyraźnie nie tylko w krajach transformacji ustrojowej po przełomie 1989 r. w Europie Środkowo-Wschodniej, ale równolegle proces jurydyzacji życia społecznego miał miejsce, i to bardzo wyraźnie, w krajach stabilnej demokracji, w tym w Europie Zachodniej i w Stanach Zjednoczonych. Niewątpliwie proces ten ma też wpływ na sposób funkcjonowania kurateli sądowej, ze względu na zakres regulacji prawem czynności kuratora oraz wzrost świadomości prawnej i rzeczywistych uprawnień podsądnych.

Szkic wskazuje wybrane kwestie, w których może się pojawiać tytułowy problem niepewności, niesprawiedliwości i dysfunkcjonalności prawa, w szczególności rozważany z uwzględnieniem specyfiki pracy kuratorów sądowych jako funkcjonariuszy publicznych, którzy w wielu przypadkach na pierwszej linii reprezentują państwo polskie, wymiar sprawiedliwości wobec podsądnych i ich rodzin, ale odpowiednio też wobec całego społeczeństwa polskiego. W pierwszej części szkicu nawiązuję luźno do schematu interpretacyjnego koncepcji prawa G. Radbrucha, a w drugiej - do rozważań na temat siły prawa Pierre’a Bourdieu. W obu przypadkach nie jest moją intencją przedstawienie poglądów tych autorów, tym bardziej, że tekst P. Bourdieu, na którym się opieram, jest od lat powszechnie znany, a tekst G. Radbrucha nie tylko jest znany, ale był też szeroko komentowany przez czołowych przedstawicieli nauki prawa w Polsce. Jak pisał na temat rzetelności analizy tekstu z zakresu nauk społecznych Michel Foucault, interpretacja takiego tekstu stanowić może tylko interpretację interpretacji, służąc jako narzędzie poznania badanego problemu, a nie odwzorowaniu poglądów autora komentowanego tekstu.

4 Konstytucja Rzeczypospolitej Polskiej z dnia 2 kwietnia 1997 r. (Dz. U. Nr 78, poz. 483 ze zm.). 


\section{Triada Radbrucha - kontekst ogólny}

Gustav Radbruch przedstawił w filozofii prawa tezę, że w każdej epoce historycznej prawo realizuje w zmiennych proporcjach trzy podstawowe idee, bez których nie mogłoby istnieć: pewności, sprawiedliwości i celowości. Pewność prawa pozwala zapobiec chaosowi, walce każdego z każdym i stanowi z tego względu konieczny element prawa. W nauce o państwie wyprowadzenie społeczeństwa z chaosu poprzez zaprowadzenie porządku, szczególnie od czasów Hobbes'a, wielokrotnie uznawano za istotę i uzasadnienie sprawowania władzy. Prawem są więc jasno określone rozkazy władcy, a posłuch dla tych rozkazów, jak również przymuszenie do ich przestrzegania stanowi pierwszy, konieczny warunek realizacji w społeczeństwie wszelkich innych wartości. Jak twierdził Hobbes, non veritas sed auctoritatis fecit legem. Władcą jest ten, kto ma zdolność zaprowadzenia w społeczeństwie porządku, a legitymizm władzy pochodzi w pierwszej kolejności właśnie od tej zdolności do narzucenia porządku, co zapobiega chaosowi, walce każdego z każdym. Także z klasycznej perspektywy prawa międzynarodowego nawiązującej do poglądów G. Jellinka, o uznaniu powstania danego państwa decyduje w pierwszym rzędzie to, że określona grupa ludzi ma faktyczną zdolność zaprowadzenia i egzekucji porządku prawnego na danym terenie wobec zamieszkującej go ludności. Jeśli grupa ta będzie też miała dostatecznie dużo siły przebicia, aby uzyskać poparcie dla swojej władzy na arenie międzynarodowej i zostanie uznana przez społeczność międzynarodową, to zasadniczo wystarczy, aby uznać ją za grupę sprawującą suwerenną legalną władzę nad ludnością na danym terenie, także w sensie prawnomiędzynarodowym. Od pierwszej połowy XIX w. próbuje się w zastępstwie dawnych zasad prawa naturalnego i religii dodawać do tych wymagań uznania państwa i jego rządu na arenie międzynarodowej także motywowane względami ludzkości zobowiązanie aksjologicznie do respektowania minimum praw ludzkich (pierwotnie chodziło o zakaz handlu niewolnikami). Niewątpliwie jednak jest to względnie często pomijany warunek uznania określonego państwa i jego władzy. Trudno też byłoby przyjąć, że warunek ten, który współcześnie wprost odnosi się do poszanowania wolności i godności ludzkiej oraz demokracji jest powszechnie spełniany na poziomie standardów minimalnych, jakie sami dla siebie przyjmujemy w Polsce i Europie. Wydaje się, że nie w pełni spełniają go też niektóre państwa, które są uznane przez Rzeczpospolitą Polską.

\section{Triada Radbrucha - pewność prawa a rola prawników i funkcjonariuszy publicznych}

Rozwój państwa prawa w skrajnie pozytywistycznym ujęciu polegałby wyłącznie na rozwoju zdolności do optymalnego i precyzyjnego dekodowania treści normy prawnej zawartej w przepisach rozumianych jako jednostki gramatyczne, technicznie wyróżnione w tekście aktu normatywnego, a zawierające elementy konstrukcyjne 
normy, nakazu, zakazu i ewentualnie dozwolenia lub kompetencji organów władzy publicznej określonych przez władzę polityczną, stosującą w tym zakresie i tworzącą na ten użytek odpowiednie pierwotne reguły uznania prawa. Precyzyjne dekodowanie normy prawnej z przepisów pozostaje więc $w$ służbie idei prawa jako woli władcy. Prawnik ma tę wolę zapisaną w przepisach odpowiednio odczytać oraz dokonać odpowiedniej subsumpcji treści normy do konkretnego stanu faktycznego, rozstrzygając, co jest w związku z brzmieniem tej normy nakazane, zakazane, dozwolone, a w jakim zakresie dana sytuacja faktyczna jest z perspektywy badanych przepisów indyferentna prawnie. Ścisłe przestrzeganie prawa przez funkcjonariusza publicznego jest konieczne, gdyż każde odejście od litery prawa stanowi automatycznie odejście od woli władcy, stanowi akt sprzeciwu lub lekceważenia władzy, która dany przepis ustanowiła. Co więcej, prawnik-pozytywista, zwłaszcza klasyczny dogmatyk, nie tyle ma słuchać, co "suweren" mówi, ale przede wszystkim w toku wykładni prawa sam ma wytworzyć "wolę" suwerena wyrażoną w danych przepisach, stosując odpowiednie zasady wnioskowania, oparte na założeniu normatywnym - a nie empirycznym - „racjonalnego prawodawcy". Mamy więc tutaj zależność wzajemną, empiryczna władza tworzy prawo, a następnie prawnicy z przepisów rekonstruują wolę tej władzy, przekładając to, co było przednormatywne, polityczne, na to, co faktycznie - zdaniem stosujących prawo - zostało zapisane w aktach normatywnych i może być odczytane jako wola racjonalnego prawodawcy. Jest oczywiste, że czasami konkretni uczestnicy procesu legislacyjnego mogą być zaskoczeni tym, jakie prawo w rzeczywistości przygotowali i za czym głosowali.

Sprawiedliwość i celowość prawa konsumuje się w ścisłym przestrzeganiu prawa, jednocześnie zarówno funkcjonariusze publiczni, jak i stosujący prawo prawnicy nie mają z tej perspektywy żadnych podstaw w systemie prawa do kwestionowania merytorycznej słuszności określonych rozwiązań prawnych będących podstawą ich działań.

Stan pewności prawa jest zawsze z tej perspektywy lepszy od chaosu, jaki wynikałby z braku pewności nakazanych, zakazanych i dozwolonych wzorów zachowań. Sprawiedliwość i celowość z tej perspektywy musiałyby się sprowadzać do dokładnego wcielania w życie woli władzy poprzez rzetelne dekodowanie norm z przepisów prawa. $Z$ tej perspektywy, zagadnieniem pozaprawnym pozostałaby kwestia zarówno legitymizmu władzy innego niż tylko wynikający z przepisów, które władza sama ustanowiła lub uznała i egzekwuje, jak i ocena zasadności jej rozkazów przybierających postać przepisów prawa. $Z$ tego punktu widzenia, konstytucja byłaby przede wszystkim deklaracją zasad skierowaną przez władzę do samej władzy, pełnić więc mogłaby wobec obywateli jedynie funkcję informacyjną odnośnie tego, jak władza funkcjonuje.

Idea pewności prawa rozwijała się $w$ dobie absolutyzmu oświeconego. W tym czasie szczególnie istotne było, aby wszelkie władcze rozstrzygnięcia wynikały z jasno wskazanej i możliwie dokładnie określonej litery prawa, a nie były przejawem arbitralności urzędniczej. Z czasem, wraz ze stopniowym rozwojem państwa industrialnego, wymaganie ścisłego przestrzegania litery prawa przez urzędników miało być zapewnione przez możliwość odwoływania się do sądu i do wyższej instancji urzędniczej, co prowadziło w XIX w. do rozwoju w Europie - obok sądów powszechnych - także 
sądownictwa administracyjnego, które miało pilnować tego, aby urzędnicy rzetelnie wcielali w życie wolę władcy, wyrażoną w przepisach prawa. Taka dominacja pewności prawa nad ideą celowości i sprawiedliwości znamionuje niektóre podstawowe zasady prawa karnego związane z nauką o przestępstwie, w szczególności samo określenie bytu przestępstwa jako podstawy odpowiedzialności karnej (art. 1 k.k. ${ }^{5}$, zasada lex certa, zakaz analogii). Znajduje ona także swój wyraz $\mathrm{w}$ - ciągle formalnie uznawanej w Polsce za istotną - karnoprocesowej zasadzie legalizmu działań organów ścigania odnośnie przestępstw ściganych z urzędu (art. 10 k.p.k. ${ }^{\circ}$ ).

Utożsamianie idei prawa z pewnością prawa, która stawała się wyznacznikiem także celowości i sprawiedliwości działania osób to prawo stosujących, było typowe dla różnych nurtów pozytywizmu prawniczego, które w drugiej połowie XIX w. zaczęły dominować w Europie jako wynik krytyki dawnych teorii prawnonaturalnych.

\section{Triada Radbrucha - sprawiedliwość jako refleks dawnych idei prawa naturalnego i zasady słuszności}

Zdaniem Chaima Perelmana, ze sprawiedliwością w prawie mamy do czynienia wtedy, gdy każdy człowiek zaliczony do określonej klasy osób ze względu na cechę istotną prawnie, zostanie zgodnie $z$ oceną według danego kryterium istotnego potraktowany tak samo jak inni oceniani ze względu na to kryterium, należący do tej samej klasy (np. wszystkich mężczyzn po czterdziestym roku życia). Każdy przejaw odmiennego - niż wynikające z litery prawa - potraktowania danej osoby byłby uznany za niesprawiedliwość. Ograniczenie się do takiego rozumienia sprawiedliwości - jako równego traktowania osób zaliczonych według danego kryterium do tej samej klasy zasadniczo prowadziłoby do jej utożsamienia z rzetelną realizacją prawa pozytywnego, a więc z pewnością prawa, co zapewniałoby wszystkim równe traktowanie według jasno określonych w prawie kategorii istotnych. W triadzie G. Radbrucha sprawiedliwość odnosi się jednak nie tylko do tej idei równego traktowania według określonego kryterium, ale także do oceny słuszności standardu samego kryterium, które jest stosowane. Już od czasów starożytnych dostrzegano, że idea prawa nie jest tożsama z literą prawa (lus versus lex), natomiast spisywanie prawa służyć miało przede wszystkim do łatwiejszego posługiwania się prawem w stosunkach społecznych, aby gwarantować ludziom ochronę istotnych wartości i regulacji stosunków społecznych, stosownie do ogólnych prawidłowości rozumianych jako zgodne z określonym modelem prawa naturalnego o pochodzeniu religijnym lub świeckim. Tak rozumiane prawo naturalne było podstawą tekstu spisanego - jak w przypadku dekalogu - lub kryterium oceny jego słuszności w przypadku praw zwyczajowych i stanowionych. W tych

\footnotetext{
5 Ustawa z dnia 6 czerwca 1997 r. - Kodeks karny (tekst jedn.: Dz. U. z 2019 r., poz. 1950 ze zm.; dalej: k.k., kodeks karny).

6 Ustawa z dnia 6 czerwca 1997 r. - Kodeks postępowania karnego (tekst jedn.: Dz. U. z 2020 r., poz. 30 ze zm.; dalej: k.p.k.).
} 
okolicznościach to właśnie odpowiednio prawo naturalne i ewentualnie prawa boskie lub reguły ogólnej słuszności (np. prawo pretorskie) stawać się mogły punktem odniesienia zarówno dla tworzenia, stosowania, jak i ewentualnej krytycznej oceny rozwiązań przyjętych w prawie pozytywnym. Prawo pozytywne, które regulowałoby stosunki społeczne w sposób rażąco sprzeczny z podstawowymi zasadami prawa naturalnego lub racjonalną zasadą słuszności, pozbawiając określonych ludzi ochrony ich praw, mogłoby być uznane za niesprawiedliwe. Co więcej, w przypadku konfliktów normatywnych, to właśnie odwołanie się do ogólnych zasad słuszności, opartych na prawie naturalnym, stawać się mogło podstawą rozstrzygnięć, które modyfikowałyby treść prawa pozytywnego. Prawo naturalne było więc sui generis prawem konstytucyjnym wieków dawnych, z tym że jego klauzule były jeszcze mniej określone niż współczesne zasady konstytucyjne. Stwierdzenie więc sprzeczności określonych rozwiązań z prawem naturalnym mogłoby być porównywane do współczesnego stwierdzenia niekonstytucyjności określonych przepisów ustawy, które zawsze powinny mieścić się w granicach odpowiedniego wzorca konstytucyjnego. Prawo naturalne czy reguły słuszności nie tyle więc mogły zastąpić literę prawa, co stanowiły probierz swoistej „prawnonaturalnej” konstytucyjności prawa pozytywnego; określały, czy swoimi treściami nie narusza podstawowych zasad prawa naturalnego, ponadto mogły mieć istotne znaczenie w toku wykładni prawa (odpowiednio - jak współcześnie - tzw. kwestia wykładni prokonstytucyjnej przepisów ustaw). Główny zarzut pozytywistów wobec prawa naturalnego dotyczył kwestii tego, kto ma ustalać jego treść oraz kto i w jakim trybie miałby ustalać, czy przepisy prawa pozytywnego mieszczą się we wzorcu instytucji spełniającej kryteria określone $w$ danej wizji prawa naturalnego. Problem prawa naturalnego wpisywał się więc w debatę na temat relacji Państwo - Kościół, ale też na temat relacji jednostka - państwo. Jeśli bowiem istnieje prawo naturalne, to oznaczać może, że także władza państwa w jakimś zakresie podlega odpowiednim ograniczeniom i jej władcze rozkazy - $w$ tym prawo pozytywne - mogą być kwestionowane przez jednostkę lub odpowiednią instytucję w imię prawa naturalnego, tak jak to w średniowieczu próbowali poprzez ekskomunikę władców egzekwować papieże. Siłą prawa natury było więc odwołanie się do pewnych wyższych standardów, które pozwalały na dokonanie oceny słuszności prawa pozytywnego i przynajmniej pozwalały wykluczyć stosowanie praw rażąco niemieszczących się w standardach - wzorcach, jakie mogłyby dla danego prawa podmiotowego, np. prawa własności czy prawa do życia, wynikać z określonej wizji prawa naturalnego. W odniesieniu do prawa naturalnego kluczowy zwrot wiązał się jednak dopiero z przejściem w myśleniu coraz bardziej od teizmu do humanizmu, a więc do idei, że najważniejsze wartości chronione prawem należy łączyć wprost z człowieczeństwem, a nie z bóstwem (Bogiem). Do tego nurtu odwoływało się oświecenie, wraz z utopią umowy społecznej, jak i Immanuel Kant ze swoją ideą państwa celów imperatywu kategorycznego (człowiek zawsze jako cel, nigdy tylko jako środek; zasada równości i uniwersalizmu postępowania). Ten ostatni nurt stał się szczególnie wpływowy na przełomie XIX i XX w. pod wpływem myśli prawniczej Rudolfa Stammlera (prawo naturalne zmiennej treści) i Leona Petrażyckiego (psychologiczna koncepcja prawa). Do sformułowań o charakterze 
prawnonaturalnym odwoływano się w XX w. w konwencji Haskiej z 1907 r., gdzie mówiono o konieczności respektowania w czasie wojny przez wszystkie strony podstawowych praw obowiązujących między cywilizowanymi narodami. Naruszenie tych praw podstawowych cywilizowanych narodów mogłoby być, jak to starano się zrealizować już po I wojnie światowej, samoistną podstawą do pociągnięcia zbrodniarzy wojennych do odpowiedzialności karnej, nawet gdyby ich działania były zgodne z prawem pozytywnym danego państwa. Do idei prawa naturalnego, wywiedzionego z określonych cech człowieka traktowanego jako zawsze naczelna wartość, a nie tylko jako byt, odpowiednio odnosiła się też koncepcja praw człowieka rozwijana szczególnie po II wojnie światowej, Deklaracja Praw i Wolności Człowieka z 1948 r. i dalsze akty prawnomiędzynarodowe i konstytucyjne przyjmowane po II wojnie światowej. Mówi się w tym kontekście o swoistej konstytucjonalizacji prawa naturalnego, którego podstawowe twierdzenia zostały odpowiednio zoperacjonalizowane i zapisane jako prawa podstawowe rangi konstytucyjnej i wiążących państwa aktów prawa międzynarodowego i prawnomiędzynarodowych postanowień o charakterze iuris cogentis. Są one w dalszym ciągu sformułowane dość ogólnie, niemniej jednak stały się, zwłaszcza w Europie pod wpływem orzecznictwa Europejskiego Trybunału Praw Człowieka, swoistym probierzem słuszności prawa pozytywnego obowiązującego w poszczególnych państwach. Jaśniej zostały określone przez opisanie w prawie pozytywnym (np. w EKPC), a także jasno określono tryb weryfikacji zgodności rozkazów władzy z wzorcem tego sui generis „prawa naturalnego” naszych czasów. Należy jednak wskazać, że ten proces ma też drugą stronę, a mianowicie, dochodzi do pozytywizacji praw człowieka jako praw podstawowych, prawa naturalnego naszych czasów. Źródłem tego prawa staje się bowiem litera konstytucji i umów międzynarodowych, a w praktyce - w dużym stopniu o kontrowersyjnym wyznaczeniu zgodności krajowego prawa pozytywnego z tym quasi-prawem naturalnym decyduje orzecznictwo, czyli działalność konkretnych urzędów, konkretnych sędziów, sądów konstytucyjnych i trybunałów międzynarodowych. Decyzje władzy, nawet gdyby były zgodne w pełni z literą ustawy, mogłyby być uznane współcześnie, czy to na mocy politycznej deklaracji państw, czy rzadziej - na podstawie działań uprawnionych trybunałów krajowych lub międzynarodowych, nawet za zbrodnicze, o ile wynikałoby to z treści praw podstawowych zawartych w najwyższych aktach prawnych krajowych i międzynarodowych. Szczególną rolę w ukształtowaniu się takiego przekonania odegrał proces norymberski głównych zbrodniarzy hitlerowskich Niemiec. Jest oczywiste, że wpływ tych koncepcji na politykę globalną jest ograniczony, a możliwość postawienia zbrodniarzy przed sądem odwrotnie proporcjonalna do siły potęgi, która ich popiera. Nie przez przypadek także proces norymberski dotyczył przywódców mocarstwa, które wojnę przegrało. Przywódca mocarstwa, które ją wygrało, Józef Stalin, chociaż był zbrodniarzem reprezentującym zbrodniczy reżim polityczny, stanął ze swoimi ludźmi po stronie oskarżycieli i sędziów, a nie w gronie oskarżonych. 


\section{Triada Radbrucha - celowość jako refleks rozwoju biurokracji i zarządzania problemami społecznymi}

W triadzie Radbrucha wydzielona jako odrębna od pewności prawa i sprawiedliwości jest celowość instytucji prawa. Może się to wiązać z przekonaniem, że w bardzo wielu przypadkach ustawodawca świadomie określa w ten sposób kształt instytucji prawa i kompetencje organów władzy publicznej, aby pozostawić możliwość podjęcia - na podstawie generalnych przesłanek prawnych - decyzji jednak zindywidualizowanej do konkretnego przypadku, co wiąże się w szczególny sposób z pojęciem tzw. decyzji uznaniowej. Należy wskazać, że celowość nie może być sprowadzona ani do jednoznacznego stosowania generalnych przepisów do indywidualnie oznaczonego adresata w konkretnej sprawie, ani nie może być utożsamiana ze sprawiedliwością rozumianą jako oddanie każdemu tego, co mu się od prawa należy (suum cuique tribuere) według jednoznacznych kryteriów zawartych bezpośrednio w samej ustawie. Można powiedzieć, że w przypadku celowości, to urzędnik na podstawie prawa, sam kierując się przekonaniem o racjonalności danego zastosowania normy prawnej, określi, jaką należy wydać decyzję, i w takiej sytuacji to właśnie taka decyzja celowa będzie sprawiedliwa. Celowość zakłada więc większe kompetencje z zakresu zarządzania danymi sprawami, które dokonuje się wprawdzie na podstawie przepisów prawa, jednak poczynione w sprawie ustalenia są dokonane przede wszystkim zgodnie $z$ wiedzą specjalistyczną, i to ona - według bardzo ogólnych kryteriów prawa o charakterze klauzuli generalnej - powinna być następnie podstawą decyzji określających prawa i obowiązki stron. Samo już rzetelne wypełnienie tego zadania przez urzędnika zapewniać ma sprawiedliwość rozstrzygnięcia. Przykładem przepisu, który kładzie nacisk na celowość w sferze zainteresowań kuratorów, jest art. 109 kodeksu rodzinnego i opiekuńczego ${ }^{7}$, w którym celowość (dobro dziecka) niewątpliwie dominuje zarówno nad ideą pewności prawa, jak i sprawiedliwości w ujęciu klasycznym (suum cuique tribuere). Pewność prawa i sprawiedliwość są w normie dekodowanej z tego przepisu podporządkowane nadrzędnej idei celowości, której prawidłowa realizacja spełni zarówno warunek zgodności z prawem pozytywnym, jak i kryterium sprawiedliwości rozstrzygnięcia. W prawie karnym natomiast mamy bardzo złożoną współzależność trzech wskazanych elementów pewności, sprawiedliwości i celowości prawa przy indywidualizacji odpowiedzialności karnej (art. 21 k.k.) i wymiaru kary (art. 55 k.k.) oraz stosowaniu sądowych przesłanek wymiaru kary, w szczególności z art. 53 i 54 k.k. Celowość odgrywa natomiast wyraźnie dominującą rolę w przepisach kodeksu karnego wykonawczego ${ }^{8}$, np. art. 62, art. 63, art. 63a, art. 63b, art. 74, art. 89, art. 145, art. 151, art. $160 \S 3$ k.k.w. We wszystkich przypadkach działania podejmowane są na podstawie prawa i w jego granicach, niemniej jednak poziom uznaniowości uzależnionej od

\footnotetext{
7 Ustawa z dnia 25 lutego 1964 r. - Kodeks rodzinny i opiekuńczy (tekst jedn.: Dz. U. z 2019 r., poz. 2086 ze zm.).

8 Ustawa z dnia 6 czerwca 1997 r. - Kodeks karny wykonawczy (tekst jedn.: Dz. U. z 2020 r., poz. 523 ze zm.; dalej: k.k.w.).
} 
celowości danego rozstrzygnięcia może być duży. Natomiast sprawiedliwość oznaczać może przede wszystkim, że każdy indywidualny przypadek będzie równie wnikliwie i bezstronnie oceniony według bardzo ogólnikowo określonych zasad kodeksowych, co rzecz jasna trudno poddaje się jakiejkolwiek innej weryfikacji niż przez ocenę samej celowości danego rozstrzygnięcia.

\section{Triada Radbrucha - podsumowanie}

Pewność prawa jest ograniczana przez możliwość dostosowania decyzji do konkretnych okoliczności indywidualnej sprawy, co w wielu przypadkach prowadzić może do rozmijania się zarówno z celowością tej decyzji, jak i poczuciem sprawiedliwości.

Jeśli jednak w społeczeństwie, jego warstwach dominujących występuje brak zaufania do władzy, to dąży się do ścisłego określenia kompetencji urzędniczych. Jeśli nie wierzy się ludziom stosującym prawo, że będą działać bezstronnie i profesjonalnie, to obronę przed niesprawiedliwością i nieracjonalnością działań widzi się w ścisłym określeniu ich kompetencji, które daje wtedy jasne podstawy do kwestionowania działań urzędnika przed organem zwierzchnim lub przed sądem. Problem ten często nagłaśniany jest przez przedsiębiorców w kontekście działania urzędów skarbowych. W takich okolicznościach przy braku zaufania do rzetelności działań organu podejmującego decyzję pewność prawa wysuwa się jako warunek konieczny sprawiedliwości. Kwestie te mogą też współcześnie dotyczyć zarówno sędziów, jak i kuratorów sądowych, przy czym - zwłaszcza odnośnie kuratorów - wydaje się, że następuje stopniowo nieco ściślejsze związanie ich działań przepisami prawa (obligatoryjność wniosku do sądu w określonych okolicznościach), co oznacza odchylenie się od dominującej idei celowości (której wyrazem jest m.in. fakultatywność złożenia wniosku do sądu w określonych okolicznościach). W XVIII w. w prawie karnym powszechne było przekonanie, że potrzebne jest maksymalnie ścisłe oznaczenie kary za dany czyn, bo tylko w ten sposób da się ograniczyć pozaprawną, nieuzasadnioną celowo i przede wszystkim niesprawiedliwą stronniczość sędziów. Utopia ta nie przetrwała w prawie karnym. Natomiast biurokracja opisywana już przez Maksa Webera w naturalny sposób musiała uwzględniać jasne opisanie kompetencji, nie po to, aby abstrakcyjną normą zawsze dać jednoznaczne podstawy rozstrzygnięcia indywidualnej sprawy, ale aby dać też w określonych prawem sytuacjach jasne ramy i podstawy dla celowych działań podjętych przez urzędników na podstawie zawartych w przepisach prawa ogólnych kompetencji. Ewentualne rozminięcie się przez urzędnika przy wydawaniu decyzji uznaniowej z celowością byłoby przejawem niesprawiedliwości, a jeśli dodatkowo naruszałoby jasno określone przepisy prawa, byłoby też ponadto przejawem oczywistej bezprawności, takiej samej jak naruszenie prawa przy decyzji związanej. Nadmienić można, ze celowość prawa stanowi też istotną przesłankę oceny prawa w sprawach spornych między podmiotami prywatnymi w prawie cywilnym i gospodarczym. 


\section{Uwagi o autopojetyczności prawa. Pole walki prawnej o interesy i wartości}

Prawo posiada swoją specyfikę jako obszar działalności człowieka, a także przedmiot analiz. W nauce prawa wyodrębnia się szczególne metody postępowania, które nie występują w innych dziedzinach nauk społecznych. W tak zwanej czystej nauce prawa zasadniczo przedmiotem studiów jest system prawa, rozumiany jako spójny system norm. Normy te są odpowiednio dekodowane z tekstów obowiązujących aktów prawnych, które na mocy odpowiednich reguł uznania zawierają wiążące wzory postępowania, wyrażone poprzez różne modalności (nakaz, zakaz, dozwolenie i pochodne) odnoszące się do wszystkich lub wskazanych generalnie ludzi na danym obszarze. Nauka prawa zawiera cały zasób metod dekodowania, odczytywania wiążących wzorów zachowania. Metody te są stosowane przez prawników w toku ich pracy zawodowej. Prawo, jak pisał poetycko Juliusz Makarewicz, można porównać do negatywu kliszy zdjęciowej, odbija ono podstawowe zasady życia społecznego na określonym etapie rozwoju cywilizacji. Można odczytać podstawowe wartości dotyczące pozycji społecznej rodziny, kobiety, mężczyzny, stosunków własności, sposobów produkcji, zasad gospodarki, tylko analizując odpowiednie teksty normatywne i wyroki sądów w konkretnych przypadkach, i to w ten sposób można wiele dowiedzieć się o funkcjonowaniu danego społeczeństwa. Należy wskazać, że w przypadku prawa cały czas istnieje problem, co jest w gruncie rzeczy podstawą, fundamentem prawa i wiedzy prawniczej. Pierre Bourdieu zwraca uwagę, że w gruncie rzeczy te fundamenty określa władza, a jej funkcjonowanie jest wypadkową gry różnych sił społecznych w danym kontekście cywilizacyjnym. Pierre Bourdieu trafnie zwraca uwagę, że głód wręcz metafizyczny "fundamentu" prawa innego niż władza prowadzi z jednej strony - do spekulacji na temat materialnego realnego określenia prawa naturalnego, czego specyficznym wyrazem jest właśnie klauzula art. 30 Konstytucji, a z drugiej - do dekonstrukcji (w nawiązaniu do filozofii Wittgensteina i Bachelarda) idei prawa, bo skoro uznają oni, że nie jest zakorzenione w prawie naturalnym, które stanowi pewną, być może użyteczną fikcję, to prawo - jak wynika z procesu dekonstrukcji jego podstaw żadnego fundamentu nie ma. W obu przypadkach mamy więc nostalgię za pewnym stałym punktem oparcia, przy czym w przypadku dekonstruktywizmu skutkiem tej nostalgii staje się nihilizm, przekonanie o braku jakichkolwiek podstaw dla prawa, a więc i dla wiedzy prawniczej. Prawo z tej perspektywy dekonstruktywistycznej są to tylko pozbawione szerszych podstaw teoretycznych konwencje językowe dość dowolnie przyjęte i następnie równie dowolnie intepretowane w toku różnych walk prawniczych specjalistów o interesy ich klientów. Wydaje się, że nawet jeśli ten dekonstruktywizm nihilistyczny nie jest wprost przywoływany w piśmiennictwie prawniczym, to de facto ma coraz większy wpływ na potoczne rozumienie prawa, nawet przez samych prawników, którzy uczą się "gry" tymi konwencjami przy załatwianiu spraw swoich klientów, rozstrzyganiu sporów w polu prawa, zaś kryterium prawdy staje się to, czy uda się wygrać coś z perspektywy danego specjalisty lub załatwić sprawę w taki sposób, jaki 
w danych okolicznościach klient lub urząd (np. skarbowy) uzna za właściwe. Tymczasem, wbrew temu skrajnemu stanowisku, konwencje prawne tworzą system, który jest zarazem prawem i państwem (prawa). System ten ma swoją własną dynamikę rozwoju i niezależnie od złożonych interakcji z przedmiotem normowania czy stosunkami społecznymi, posiada własną autonomiczną dynamikę działania, w ramach której następuje też jego rozwój i zmiana, podlegające określonym prawidłowościom. Prawidłowości te są determinowane nie tylko regułami języka i zasad wnioskowań prawniczych, a więc wiedzą, ale także władzą, czy raczej walką o władzę, jaką toczą specjaliści w toku postępowań przed organami publicznymi, a zwłaszcza sądami. Wynik tej walki nie jest ani arbitralny, ani zawsze w pełni przewidywalny, w szczególności, gdy chodzi o sprzeczne wartości i interesy społeczne, które są podstawą sporu toczonego już w specjalistycznym języku prawniczym. Prawo wyróżnia się jako pole działania osób, które mają szczególne kwalifikacje do tego, aby określać odpowiednio stosunki prawne. Obok zwykłych funkcjonariuszy publicznych szczególne zadania wypełniają w tym systemie prawnicy w różnych rolach, przy czym nadrzędną rolę przypisuje się sędziom, których to zawód jest też wyróżniony w polskiej konstytucji. Sędziowie w interpretacji P. Bourdieu wychodzą poza nihilizm prawniczy i starają się poprzez swoją praktykę i egzegezę prawa racjonalizować prawo pozytywne. Dokonują tego dzięki logicznej interpretacji tekstu, zgodnie z zasadami wykładni prawa, co pozwala na zachowanie spójności całości systemu prawnego i jednocześnie na odkrywanie nieprzewidzianych konsekwencji tekstów aktów normatywnych oraz ich wzajemnych zależności, w ten sposób wypełniając swoiste luki prawne (m.in. stosując odpowiednio reguły inferencyjne). Sędziowie nie tworzą w ten sposób prawa, przynajmniej w klasycznym systemie Europy kontynentalnej, w tym w Polsce, ale też na pewno nie można ich określić mianem „ust ustawy". Prawo będące wynikiem interpretacji dokonanej w toku sądowej wykładni prawa po odpowiednim naświetleniu interpretacji prawa w kontekście przedstawionego stanu faktycznego nie jest prostą deklaracją na tle tego stanu faktycznego ogólnych wzorów nakazanego czy zakazanego, lub dozwolonego postępowania, zawartych w przepisie. Prawo takie, jakie stosujemy, nie jest tylko zapisane w tekście prawa pozytywnego, lecz pozostając z tekstem związane, rodzić się może ze sporu o prawo, w szczególności toczonego przed sądem. Także decyzje organów władzy publicznej niejednokrotnie do tych sądowych rozstrzygnięć mogą się odwoływać jako do istotnego argumentu, który ma zapewnić trwałość wydawanej decyzji, jako zakorzenionej w ugruntowanym sposobie rozumienia idei prawa. Spór o prawo nie jest jednak zwykłym sporem obywateli ze sobą lub organami władzy publicznej o to, co jest słuszne i co się komu należy, lecz jest ustalaniem przez specjalistów działających w polu prawa sensu systemu prawa odnośnie danego przypadku będącego przedmiotem zainteresowania. Pole prawa, w którym kształtuje się tak rozumiany system prawa za P. Bourdieu należy określić jako przestrzeń społeczną zorganizowaną wokół przekształcenia bezpośredniego konfliktu między określonymi stronami w prawnie regulowaną debatę, która odbywa się między profesjonalistami działającymi jako pełnomocnicy (stron, w tym interesu publicznego, społeczeństwa). To w ramach tej debaty przedmiot sporu zostaje przekształcony w „fakty relewantne prawnie”, które dopiero 
są przedmiotem „obiektywnego" rozstrzygnięcia. Rozstrzygnięcie to określa władczo poddane mu stosunki (prawa). Ten proces przekształcania problemu i sporów ludzkich w "fakty urzędowe" czy też „sądowe” z perspektywy kryminologii i penologii ostro krytykował swego czasu Nils Christie. Sugerował, że w ten sposób sfera owego państwa lub prawa zawłaszcza ludzkie konflikty w celu ustanowienia własnego, bardziej autorytarnego porządku nałożonego przez państwo prawa na jednostki i społeczności. Z tej krytyki czerpał w prawie karnym inspiracje ruch sprawiedliwości naprawczej. Być może rozważania na temat przywrócenia sądów „zwykłych ludzi” (sądów pokoju) w drobnych sprawach sąsiedzkich konfliktów są też wyrazem dążenia do „zwrócenia” ludziom ich konfliktów zawłaszczanych przez państwo w polu prawa, nawet jeśli główna motywacja podobnych reform ma też aspekt ekonomiczny i prakseologiczny.

Tymczasem we współczesnych państwach rozwiniętych widać wyraźnie narastający proces jurydyzacji, który polega na regulowaniu prawem coraz większej gamy ludzkich zachowań i jednocześnie poddawaniu rozstrzygania spornych spraw profesjonalnym osobom działającym w polu prawa, z faktycznym mocnym ograniczeniem lub wręcz wyłączeniem z tej działalności zwykłych ludzi. W praktyce więc poważne kwestie życiowe muszą zostać przetłumaczone na język prawa i dopiero wtedy są rozstrzygane już w ramach walki o interesy, która toczyć się ma między profesjonalistami w polu prawa. Pole prawa zakłada istnienie wspólnego zasobu znaków i zasad, które łączą wszystkich uczestniczących w działaniach w tym polu profesjonalistów. Ta jedność wiedzy i praktyki stwarza wrażenie uniwersalności zarówno sposobu działania, jak i wynikających z niego rozstrzygnięć, które dotyczą spraw społecznych. W ten sposób poprzez wrażenie uniwersalności utrwala się legitymizm władzy, która ma moc zaprowadzania porządku, przy czym w toku tak prowadzonych ostrych nawet sporów wyklucza się przemoc, zwroty obraźliwe. Wszelkie emocje i ewentualne gwałtowne reakcje zastąpione zostają przez odpowiednie profesjonalne sformułowania. Tym, co jednoczy wszystkich specjalistów, jest tekst prawa i odpowiednie umiejętności jego dekodowania i przekonywania do swojej interpretacji. Proces ustalania prawa w przypadku, gdy jest ono przedmiotem sporu przed urzędem, a w szczególności przed sądem, jest to więc zarówno walka o wiedzę, jak i w konsekwencji - walka o władzę. Zwycięska w tej walce interpretacja ostatecznie ma moc tworzenia rzeczywistości społecznej, określanej w sposób autorytatywny prawomocną decyzją organu władzy publicznej lub prawomocnym wyrokiem sądu. Fakty - jak wskazałem wyżej - muszą w toku tej walki zostać przetworzone na okoliczności relewantne prawnie, co także wymaga tłumaczenia rzeczywistości w taki sposób, aby korzyść odniosła z tego strona, której to dotyczy. Jest oczywiste, że nie może być większej szkody dla państwa prawa, niż ta, jaka wynikać mogłaby z okoliczności, że sędzia okazałby się fałszywym tłumaczem ludzkich spraw na język prawa, ignorantem - lub co jeszcze gorsze - zwykłym oszustem czy też przestępcą. To strach przed nieuczciwym sędzią prowadził w XVIII w. do postulatu ścisłej pewności prawa karnego, także w odniesieniu do kary, a współcześnie prowadzi do kodyfikacji zasad zawodu sędziego, zapewnienia niezależności sądu i niezawisłości sędziowskiej w konstytucji, ale także mechanizmów kontroli, aby ludzie 
pozbawieni zasad moralnych nie przenikali do tej grupy zawodowej, gdyż stanowić to może ogromne zagrożenie dla państwa prawa i całego życia społecznego.

\section{Podsumowanie}

Państwo prawa należy do sfery ideału, zaś sferę rzeczywistości - być może trafniej niż koncepcja demokratycznego państwa prawa - opisuje wypowiedź jednego z sędziów - respondentów w badaniach "kultur penalnych", który stwierdził, że zawód sędziego "wzmaga poczucie zagrożenia, pokazuje absurdalność działań urzędniczych i całkowite nieliczenie się z kosztami funkcjonowania państwa" ${ }^{\prime \prime}$. W tym kontekście instytucjonalnym swoje zadania realizuje na podstawie prawa kurator zawodowy. Odpowiednia mediacja między rzeczywistością, w której naprawdę żyją podopieczni i działa kurator sądowy, a "faktami sądowymi" jest jednym z kluczowych wyzwań w pracy kuratora sądowego. Praca kuratora sądowego dotyczy w szczególności ustalenia okoliczności istotnych dla wymierzenia sankcji karnej lub zastosowania środka na podstawie ustawy o postępowaniu w sprawach nieletnich czy kodeksu rodzinnego i opiekuńczego, lub dla realizacji orzeczonych sankcji, w szczególności w ramach wzorów działania określonych w kodeksie karnym wykonawczym. Także w tym zakresie jego ustalenia są jednak co do zasady ważną, ale tylko podstawą decyzji sędziego i tylko wyjątkowo mogą prowadzić do tymczasowych postanowień wprost zmieniających sytuacją prawną podopiecznego (por. np. art. 430 § 4 k.k.w.).

Kurator sądowy w swojej pracy w wielu przypadkach występuje jako swoisty mediator i tłumacz problemów społecznych, które mają podopieczni, na język prawa, w którym sąd określa następnie fakty relewantne prawnie i dokonuje rozstrzygnięć według uniwersalnych reguł prawa. Kurator zawodowy tłumaczy z jednej strony, na użytek najważniejszego aktora w polu prawa - sędziego - problemy danych rodzin (kurator rodzinny) czy kontekst społeczny, w którym funkcjonuje sprawca, ale też z drugiej - wtórnie w toku wykonywania nadzorów i dozorów dbać musi o rzetelne tłumaczenie racji prawa na racje społeczne, które będą jasne merytorycznie i jednocześnie możliwie przekonujące dla podopiecznych i innych osób, których to może dotyczyć. Bez przetłumaczenia racji sądu i ich przedstawienia tak, aby były jednocześnie zrozumiałe i akceptowane, proces resocjalizacji czy naprawy relacji społecznych, w tym readaptacji społecznej skazanego, może być utrudniony, lub wręcz uniemożliwiony. Ważne, aby to tłumaczenie było poprawne w obydwie strony, gdyż w innym przypadku nastąpić może zakłócenie w pracy wymiaru sprawiedliwości, a realia będące podstawą decyzji sędziego przestaną odpowiadać rzeczywistej sytuacji podsądnych, którzy z kolei nie będą rozumieć i akceptować decyzji wymiaru sprawiedliwości, czy to w sprawach rodzinnych, czy w sprawach karnych. Dlatego w działaniu kuratora sądowego niezwykle ważne jest stałe pilnowanie podstaw i granic prawa określającego

9 Por. wyniki badań [w:] J. Królikowska, Sędziowie o karze, karaniu i bezkarności. Socjologiczna analiza sędziowskiego wymiaru kary, Warszawa 2020, s. 313. 
jego uprawnienia i obowiązki jako organu i przedstawiciela sądu. Jednocześnie powinien ze względu na cel sprawowanej funkcji dbać o poszanowanie interesów i dobra podsądnych, z którymi ma aktywnie i z życzliwością współdziałać dla ich dobra, co jest szczególnie wyraziste w sądach rodzinnych, ale odpowiednio wiąże się z zadaniami resocjalizacyjnymi w kurateli w sprawach karnych. Kurator zawodowy, działając w ramach obowiązującego prawa, ma spełniać określone funkcje wychowawcze i resocjalizacyjne, diagnostyczne, profilaktyczne oraz kontrolne, których kształt w ramach prawa określa przyjęta pragmatyka wykonywania zawodu i jego zindywidualizowana profesjonalna wiedza oraz doświadczenie zawodowe. Jednym ze stałych doświadczeń kuratora sądowego jest odczuwanie niepewności prawa, w tym odnośnie własnych działań i zaniechań oraz ich możliwej oceny zarówno przez sąd, jak i skarżących podsądnych, a także doświadczanie wątpliwości co do celowości niektórych podejmowanych działań czy mierzenie się z poczuciem niesprawiedliwości w ocenie własnej pracy ze strony podsądnych. Natomiast jego własnym zadaniem, osiąganym dzięki doświadczeniu i szkoleniom jest praca nad tym, aby wszystkie wskazane elementy prawa odpowiednio obecne były w jego pracy i przekładały się na doświadczenia podsądnych i ich grup odniesienia, budując u nich poczucie zgodności z prawem, celowości i sprawiedliwości działań podejmowanych przez kuratora na podstawie decyzji wydawanych przez sąd w imieniu Rzeczypospolitej Polskiej.

\section{Literatura}

Bourdieu P., The Force of Law Toward a Sociology of the Juridical Field , "The Hastings Law Journal" 1987, nr 38.

Christie N., Conflicts as Property, ,',The British Journal of Criminology" 1977, t. 17.

Die normative Kraft des Faktischen. Das Staatsverständnis Georg Jellineks, red. A. Anter, Leipzig 2004.

Dupret B., Prawo w naukach społecznych, tłum. J. Stryjczyk, Warszawa 2010.

Foucault M., Gry władzy, przekł. T. Komendant, "Literatura na Świecie” 1988, nr 6.

Grimme K., Die Rechtfiguren einer "Normativität des Faktischen". Untersuchungen zum Verhältnis von Norm und Faktum und zur Funktion der Rechtsgestaltungsorgane, Berlin 1971.

Hart H.L.A., Pojęcie prawa, tłum. i wstęp J. Woleński, Warszawa 1998.

Hobbes T., Lewiatan, czyli materia, forma i władza państwa kościelnego i świeckiego, tłum. C. Znamierowski, Warszawa 1954.

Izdebski H., Historia administracji, Warszawa 2001.

Jellinek G., Allgemeine Staatslehre, Berlin-Heidelberg 1921.

Kervégan J.F., Hegel, Carl Schmitt. Le politique entre spéculation et positivité, Paris 1992.

Kostrubiec J., Nauka o państwie w myśli Georga Jellinka, Lublin 2015.

Królikowska J., Sędziowie o karze, karaniu i bezkarności. Socjologiczna analiza sędziowskiego wymiaru kary, Warszawa 2020.

Królikowska J., Kontekst socjologiczny pracy kuratora sądowego [w:] Profilaktyka i readaptacja społeczna - od teorii do doświadczeń praktyków, red. E. Bielecka, Białystok 2006.

Legal Professsions at the Crossroads, red. D. Jemielniak, Frankfurt am Main 2014. 
Luhmann N., Systemy społeczne. Zarys ogólnej teorii, przekł. M. Kaczmarczyk, Kraków 2007.

Makarewicz J., Prawo karne. Wykład porównawczy, Lwów-Warszawa 1924.

Perelman Ch., O sprawiedliwości, tłum. W. Bieńkowska, Warszawa 1959.

Petrażycki L., O nauce, prawie i moralności. Pisma wybrane, wyb. J. Licki, A. Kojder, oprac. idem, Warszawa 1985.

Pietrzak M., Demokratyczne państwo prawne, „Przegląd Humanistyczny” 1989, nr 6.

Prawo i ład społeczny. Integralnokulturowa analiza zagadnienia racjonalności. Artykuły i szkice, red. J. Utrat-Milecki, Warszawa 2011.

Radbruch G., Filozofia prawa, przekł. E. Nowak, Warszawa 2012.

Schmitt C., Théorie de la Constitution, przekł. L. Déroche, Paris 1993.

Społeczne role prawników sędziów, prokuratorów, adwokatów, red. G. Skąpska, J. Czapska, M. Kozłowska, Wrocław-Warszawa-Kraków-Gdańsk-Łódź 1989.

Szyszkowska M., Europejska filozofia prawa, Warszawa 1993.

Utrat-Milecki J., Etos praw człowieka [w:] Etyka służb społecznych, red. W. Kaczyńska, Warszawa 2010.

Utrat-Milecki J., Ius Aequum?, ,Studia luridica” 1998, t. 35.

Utrat-Milecki J., Kontekst kulturowy recepcji i krytyki prawno-naturalnej myśli św. Tomasza z Akwinu, , Przegląd Tomistyczny 2007, nr 1.

Utrat-Milecki J., Polityczność przestępstwa, Warszawa 2007.

Waltoś S., Hofmański P., Proces karny. Zarys systemu, Warszawa 2018.

Wróbel W., Zoll A., Polskie prawo karne. Część ogólna, Kraków 2010.

Zajadło J., Dziedzictwo przeszłości. Gustav Radbruch portret filozofa, prawnika, polityka i humanisty, Gdańsk 2007.

Zajadło J., Formuła Radbrucha. Filozofia prawa na granicy pozytywizmu prawniczego i prawa natury, Gdańsk 2001.

Zalewski W., Sprawiedliwość naprawcza, początek ewolucji polskiego prawa karnego?, Gdańsk 2006.

Zimmermann J., Prawo administracyjne, Warszawa 2008.

\section{Streszczenie}

\section{Jarosław Utrat-Milecki}

Penologia jako podstawa polityki kryminalnej. Wybrane teoretyczne kwestie prawne związane z pracą kuratora sądowego

W pracy przedstawiam z perspektywy penologicznej teoretyczne problemy związane z prawem w działaniu, które odpowiednio dotyczą realizacji zadań przez kuratora sądowego. Analizuję z perspektywy penologicznej różne aspekty teoretyczne prawa w działaniu ze szczególnym uwzględnieniem prawa karnego i środków profilaktycznych chroniących dobro dziecka. W pracy uwzględniam w szczególności teoretyczne poglądy na prawo Georga Jellinka, Gustava Radbrucha i Pierre'a Bourdieu. Podkreślam, że brak pogłębionej analizy penologicznej prowadzonej polityki kryminalnej, i w szczególności, pracy kuratora może mieć negatywny wpływ na jej efektywność jako środka zapobiegania przestępczości i patologii społecznej. 


\section{Summary}

\section{Jarosław Utrat-Milecki}

\section{Penology as the foundation of crime prevention.}

\section{Selected theoretical legal issues related to the work of a probation officer}

In the article the author presents, from the penological perspective, selected theoretical problems related to the concept of law in action which concern the performance of tasks by a probation officer. First, he analyses different theoretical approaches to the concept of law in action with particular emphasis on criminal law and preventive measures protecting child welfare. In particular, the author refers to the theoretical concepts of law in action of Georg Jellinek, Gustav Radbruch and Pierre Bourdieu. He emphasizes that the lack of more profound penological analysis of criminal policy and, in particular, the work of a probation officer may have a negative impact on its effectiveness as a means of crime and social pathology prevention.

Słowa kluczowe: penologia, prawo w działaniu, kurator sądowy

Keywords: penology, law in action, probation officer 